\title{
Pelatihan dan Workshop Pendekatan dan Teknik Konseling Expressive Therapy bagi Guru BK SLTP/ MTs.N Kota Padang
}

\author{
Syahniar Syahniar ${ }^{1 *}$ \& Lisa Putriani ${ }^{2}$ \\ ${ }^{12}$ Universitas Negeri Padang \\ Đ- e-mail: syahniar@konselor.org
}

\begin{abstract}
Abstrak
Kegiatan pelatihan dan workshop ini dijalankan berdasarkan banyaknya fenomena siswa yang tidak mampu menyampaikan perasaan dan pemikirannya dalam proses konseling. Hal ini berkemungkinan terjadi karena dampak psikologis dari berbagai kejadian, salah satu contohnya adalah ketakutan terhadap ujian nasional. Dampak psikologis ini, seharusnya bisa diminimalkan dan/atau dihilangkan apabila siswa mau menyampaikan permasalahannya kepada guru BK/Konselor. Untuk itu guru BK/konselor harus memiliki wawasan dan keterampilan tentang berbagai pendekatan dan teknik dalam konseling. Salah satunya adalah teknik konseling expressive therapy. Para ahli terapi ekspressif meyakini bahwa individu berbeda dalam mengekspresikan apa yang ada dalam dirinya, ada individu yang lebih terbuka mengungkapkan apa yag terasa dalam dirinya, termasuk mengkomunikasikan kecemasan yang dirasakannya. Sebaliknya ada individu lainnya agak tertutup tidak bisa mengkomunikasikan secara langsung apa yang terasa dan menjadi beban pikirannya, termasuk mengkomunikasikan kecemasan yang dirasakannya. Untuk itu konselor perlu memiliki metode yang bervariasi dalam kegiatan pelayanan konseling, sehingga konselor dapat mengembangkan kemampuan klien untuk mengkomunikasikan secara efektif dan otentik apa yang ada dalam dirinya dan apa yang menjadi beban pikirannya, serta yang menjadi obyek kecemasannya. Pelatihan dan workshop ini diberikan kepada guru BK/Konselor tingkat SLTP/MTsN se Kota Padang dalam pertemuan MGBK Kota Padang.
\end{abstract}

Kata kunci: ekspressive therapy

Copyright (C) 2017 IICET (Indonesia) - All Rights Reserved

Indonesian Institute for Counseling, Education and Therapy (IICET)

\section{PENDAHULUAN}

Berbagai peristiwa dalam dunia pendidikan seringkali membawa dampak bagi masyarakat, salah satu bentuk peristiwa itu adalah ujian nasional dengan berbagai aspeknya. Ujian nasional merupakan peristiwa yang mencemaskan (Ririmasse, R. S. 2006; Taufik, T., \& Ifdil, I. 2013) dan mendebarkan berbagai pihak seperti siswa, guru, guru BK/konselor sekolah, dan orangtua. Seorang guru BK/konselor yang profesional seharusnya tidak perlu larut dalam kecemasan ini. Guru BK/konselor perlu mencari solusi bagaimana siswa merasa bahwa ujian nasional itu perlu disikapi dengan cara yang positif. Guru BK/konselor profesional perlu mencari solusi untuk mengatasi rasa cemas siswa, sehingga siswa menghadapi ujian nasional terbebas dari berbagai bentuk kecemasan. Ada berbagai terapi yang dapat digunakan oleh guru BK/konselor, salah satu bentuk terapi yang bisa digunakan oleh guru BK/konselor adalah terapi ekspressif.

Para ahli terapi ekspressif meyakini bahwa individu berbeda dalam mengekspresikan apa yang ada dalam dirinya, ada individu yang lebih terbuka mengungkapkan apa yang terasa dalam dirinya (Ifdil, I. 2010), termasuk mengkomunikasikan kecemasan yang dirasakannya. Sebaliknya ada individu lainnya agak tertutup tidak bisa mengkomunikasikan secara langsung apa yang terasa dan menjadi beban pikirannya, termasuk 
mengkomunikasikan kecemasan yang dirasakannya. Untuk itu konselor perlu memiliki metode yang bervariasi dalam kegiatan pelayanan konseling, sehingga konselor dapat mengembangkan kemampuan klien untuk mengkomunikasikan secara efektif dan otentik apa yang ada dalam dirinya dan apa yang menjadi beban pikirannya, serta yang menjadi obyek kecemasannya.

Terapi ekspressif dikenal sebagai suatu terapi dalam konseling dan psikoterapi di mana klien dapat mengkomunikasikan dan mengekspresikan perasaan-perasaan dan pemikiran-pemikirannya melalui aktifitas yang berkaitan dengan seni, musik, tari-tarian, drama, puisi, serta permainan. Terapi ekspressif disebut juga dengan "Terapi Seni Kreatif". Khususnya seni, musik, drama dan puisi (National Coalition of Creative Arts Therapies assosiation INCCTA 2004).

Selanjutnya Pies (2008) mengemukakan bahwa terapi ekspressif merupakan suatu bentuk terapi yang digunakan dalam psikoterapi dan konseling yang bertujuan untuk menyalurkan emosi dan pemikiran individu, mereduksi stres dan konflik, melalui media drama, membuat gambar dan musik.

Dari berbagai pendapat di atas dapat disimpulkan bahwa terapi ekspressif adalah suatu bentuk terapi yang dapat digunakan oleh konselor membantu klien mengungkapkan dan mengkomunikasikan perasaanperasaan, pemikiran-pemikiran melalui media dan kegiatan yang berkaitan dengan aktifitas kesenian, taritarian, darama, puisi, dan bentuk permainan.

Oleh karena itu perlu disiapkan upaya terintegrasi untuk meningkat kompetensi guru BK/konselor di sekolah dalam hal penggunaan pendekatan dan teknik konseling. Atas dasar itu penulis berkeinginan untuk mengadakan pelatihan dan workshop pendekatan dan teknik konseling expressive therapy bagi guru BK/konselor SLTP/MTsN Kota Padang. Kegiatan ini bisa dilakukan dalam pertemuan MGBK yang diadakan setiap hari Kamis.

\section{Ekspresive Therapy}

Materi pendekatan/teknik konseling ekspressive therapy diambil dari berbagai sumber agar dapat dijadikan dasar dalam penerapan dan peningkatan keterampilan guru BK/Konselor di sekolah dalam menangani berbagai masalah siswa. Materi tersebut diantaranya:

\section{Bentuk Pengaplikasian Terapi Ekspressif}

a) Terapi Seni, adalah suatu bentuk terapi dengan menggunakan media seni, dengan menggunakan media, imaginasi, dan proses kreatif. Klien diberi kesempatan untuk merefleksikan serta mengkomunikasikan, kemampuan, kepribadian, minat, perhatian, dan konflik-konflik yang ada dalam dirinya. Terapi ini bertujuan untuk mereduksi konflik emosional, kesadaran diri, kemampuan sosial, pengendalian tingkah laku, pemecahan masalah, mereduksi kecemasan, mengembangkan self esteem (American Art Therapy Association 2004).

b) Terapi Musik, adalah suatu terapi dengan menggunakan media musik untuk membantu klien mengungkapkan keadaan psikologis, fisik, pikiran, atau fungsi-fungsi sosial kesehatan individu, dan atau masalah-masalah pendidikan (American Music Therapy Association,2004)

c) Terapi Drama, adalah suatu kegiatan sistematis dan mendalam dengan mengunakan proses drama, untuk menggali potensi ,emosi dan integrasi fisik, serta perkembangan individu. Ini adalah suatu pendekatan yang aktif untuk membantu klien mengungkapkan keadaan dirinya untuk dicarikan solusinya, dengan menggunakan katarsis, memahami pengalaman secara mendalam, memahami imaginasi, dan memahami diri secara mendalam melalui bermain peran (National drama Therapy association, 2004)

d) Terapi Gerakan/Tarian, asumsi dasarnya adalah bahwa badan jasmani dan pemikiran adalah saling berhubungan dan ini banyak dibahas dalam psikoterapi. Proses gerakan yang ditampilkan berhubungan dengan keadaan emosi, pemikiran, dan psikologis dari individu. Terapi tarian dan/gerakan melihat dampak yang terjadi dalam perasaan, pemikiran, fungsi fisik dan tingkah laku (NCCATA,2004).

e) Terapi Puisi/dan Biblio terapi, adalah suatu bentuk terapi untuk melihat ekspressi diri klien dengan menggunakan media puisi atau karangan yang digunakan untuk penyembuhan dan pengembangan diri. (NCCATA,2004)

f) Terapi permainan suatu bentuk terapi dengan menggunakan proses interaksi interpersonal di mana terapis mencoba menggunakan proses permainan sebagai cara untuk membantu klien mengkomunikasi apa yang terjadi dalam dirinya seprti masalah-masalah psikologis dan untuk mengembangkan kemampuan klien mengekspressi apa yang dia rasakan secara optimal (Boyd-Webb, 1999; Landreth,1991). 
Knill et al. (1995) mengemukakan bahwa terapi ekspresif meliputi kegiatan yang unik, yang masingmasingnya memiliki perbedaan. Peranan terapis tergantung bagaimana aplikasi, klien, setting, dan objek yang akan dilaksanakan.

\section{Peranan Terapi Ekspressif dalam Pemberian Bantuan}

Secara umum baik dalam konseling maupun psikoterapi, terapi ekressif dapat dilakukan baik secara individual, keluarga, maupun secara kelompok. Seorang konselor ekspressif terlebih dahulu menjelaskan pengertian, menggunakan berbagai bentuk permainan, musik, puisi, cerita dan sebagainya. Tergantung kepada keaadaan klien, terapis menggunakan kegiatan pengakraban dengan permainan, gerakan, bercerita, rileksasi dan sebagainya. Dalam pelaksanaan terapi ekspressif boleh menggunakan satu atau lebih model terapi ekspressif seperti drama, lalu ada permainan atau pembacaan puisi dan sebagainya.

\section{Karakteristik Unik Terapi Ekspressif}

Terapi ekspressif merupakan terapi yang memiliki keunikan yang dipakai dalam konseling dan psikoterapi karena memiliki beberapa karakteristik khusus. Keunikan terapi eksperessif dapat dibatasi dalam hal: (a) Ekspresi diri, (b) Partisipasi aktif, (c) imaginasi, (d) Keterkaitan dan hubungan antara pemikiran dan tubuh jasmani

\section{Ekspressi Diri.}

Seluruh terapi ekspressif, pada dasarnya bertujuan untuk mengembangkan eksplorasi diri individu. Terapi ekspresif tidak hanya mengembangkan eksplorasi diri tetapi dalam setiap episode terapinya juga mengembangkan bagaimana klien mampu mengkomunikasikan apa yang terasa dan terpikir dalam diri klien (Gladding,1992). Secara mendasar konselor dan klien bekerjasama mengekspresikan diri dalam bentuk mengekpressikan perasaan, persepsi, mengembangkan pemahaman diri.

\section{Partisipasi Aktif}

Terapi ekspressif dikenal dalam psikologi sebagai “action therapies" (Weiner,1999) sebab metode yang dipakai berorientasi action, di mana klien secara aktif mengeksplorasi diri dan mengkomunikasikan pemikiran dan perasaannya melalui media musik, drama, gerakan dan tarian, permainan dan sebagainya.

\section{Imaginasi}

Levinne (1999) mengemukakan bahwa imajinasi merupakan dasar yang dipakai terapi ekspressif dalam kegiatan seni dan permainan. McNiff (1992) meyakini bahwa imajinasi merupakan hal yang pokok dan mendasar dalam keseluruhan terapi ekspressif.

\section{Keterkaitan dan Hubungan antara Tubuh Jasmani dan Pemikiran}

National Center for Complementary and Alternative Medicine (NCCAM,2004) mengungkapkan bahwa hubungan antara badan jasmani dengan pemikiran. Kemampuan berpikir mempengaruhi fungsi-fungsi jasmniah tubuh.

\section{SIMPULAN DAN SARAN}

Beberapa hal yang dapat menjadi kesimpulan dari hasil kegiatan pelatihan dan workshop pendekatan/teknik ekspressive therapy adalah setelah mengikuti kegiatan pelatihan dan workshop pendekatan/teknik konseling ekspressive therapy, Guru BK/Konselor sekolah tingkat SLTP/MTsN di Kota Padang mendapatkan wawasan, pengetahuan, pemahaman dan keterampilan berkenaan dengan ekspressive therapy, setelah mengikuti kegiatan pelatihan dan workshop pendekatan/teknik konseling ekspressive therapy, Guru BK/Konselor sekolah tingkat SLTP/MTsN di Kota Padang dapat melakukan konseling dengan pendekatan ekspressive therapy, sehingga dapat mengatasi berbagai persoalan yang dihadapi siswa, dan Pelatihan dan workshop ini membawa pengetahuan dan nuansa baru dalam perkembangan keilmuan konseling setempat, terutama dalam peningkatan keterampilan guru BK untuk melakukan konseling dengan berbagai pendekatan dan teknik.

Adapun saran terkait kegiatan pengabdian kepada masyarkat dalam penerapan IPTEKS ini adalah para konselor sekolah hendaknya senantiasa meningkatkan wawasan, pengetahuan, ketrampilan, nilai dan Sikap dalam menjalankan tugasnya dengan selalu mengikuti seminar dan workshop yang diadakan di berbagai tempat 


\section{DAFTAR RUJUKAN}

American Art Therapy Association. (2004). National Coalition of Creative Arts Therapies Associations, Inc. American Music Therapy Association. (2004). National Coalition of Creative Arts Therapies Associations, Inc.

Cathy A.M. (2005). Expressive therapy: Guildford. Publication

China Federation of Literary and Art Circles Publishing Corporation . (2010). ISBN 978-7-5059-7014-4.

Ifdil, I. (2010). Pendidikan Karakter dalam Bimbingan dan Konseling. Pedagogi: Jurnal Ilmu Pendidikan, $10(2), 55-61$.

Irving B. Weiner. (1999). Handbook of psychology:Johns Willwy \& Sons. Inc

National drama Therapy association. (2004). National Coalition of Creative Arts Therapies Associations, Inc.

Paolo J. Knill, Ellen G. Levine, Stephen K. Levine. (1995). Principles and Practice of Expressive Arts Therapy: Toward a Therapeutic ...Pentoville road.

Ririmasse, R. S. (2006). Hubungan Antara Pengaturan Waktu Belajar Dengan Kecemasan Menghadapi Ujian Akhir Nasional (UAN).

Samuel T. Gladding. (1998). Creative art in counseling: A multicultural perspective.arts in psychotherapy

Siti Walidatul, A. (2014). Penerapan Metode Maternal Reflektif (MMR) dalam Pembelajaran Pendidikan Agama Islam Bagi Anak Tunarungu di SDLB B Yakut Purwokerto Banyumas (Doctoral dissertation, IAIN Purwokerto)

Taufik, T., \& Ifdil, I. (2013). Kondisi Stres Akademik Siswa SMA Negeri di Kota Padang. Jurnal Konseling dan Pendidikan, 1(2), 143-150. 